\title{
PERANAN INFOMASI AKUNTANSI TERHADAP KEBERHASILAN UMKM DI KOTA LANGSA
}

\author{
Mastura*, Mutia Sumarni**, Zulfa Eliza*** \\ * Fakultas Ekonomi dan Bisnis Islam IAIN Langsa \\ ** Fakultas Ekonomi dan Bisnis Islam IAIN Langsa \\ *** Fakultas Ekonomi dan Bisnis Islam IAIN Langsa
}

\begin{abstract}
Among the leading Micro, Small and Medium Enterprises in Langsa are shrimp paste, soy sauce and touco, but it is unfortunate, those Enterprises have not paid attention to the importance of accounting knowledge and have not fully used accounting information in conducting their businesses. Accounting information is very importance to the success of Micro, Small and Medium Enterprises in Langsa City and whether accounting information can increase the success of Micro, Small and Medium Enterprises in Langsa City. This study is a qualitative study whose research subjects are shrimp paste, soy sauce and touco businesses in Langsa City. The results showed that accounting information plays an important role in the success of Micro, Small and Medium Enterprises in Langsa City and can increase the success of Micro, Small and Medium Enterprises in Langsa City
\end{abstract}

Keywords: Operational Information, Management Information, Financial Information, Success

\begin{abstract}
Abstrak
Salah satu Usaha Kecil Mikro Menengah yang unggul di kota Langsa adalah terasi, kecap dan touco,Namun sangat disayangkan, pelaku Usaha Kecil Mikro Menengah di kota Langsa belum memperhatikan pentingnya pengetahuan akuntansi dan belum sepenuhnya menggunakan informasi akuntansi dalam menjalankan bisnisnya.Penelitian ini bertujuan untuk mengetahui peranan informasi akuntansi terhadap keberhasilan Usaha Kecil Mikro Menengah di Kota Langsa dan apakah informasi akuntansi dapat meningkatkan keberhasilan Usaha Kecil Mikro Menengah di Kota Langsa. Penelitian ini adalah penelitian kualitatif yang subjek penelitiannya adalah pelaku usaha terasi, kecap dan touco di Kota Langsa. Hasil penelitian menunjukkan bahwa informasi akuntansi mempunyai peran terhadap keberhasilan Usaha Kecil Mikro Menengah di Kota Langsa dan dapat meningkatkan keberhasilan Usaha Kecil Mikro Menengah di Kota Langsa
\end{abstract}

Kata Kunci : Informasi Operasi, Informasi Manajemen, Informasi Keuangan, Keberhasilan 


\section{PENDAHULUAN}

Peran UKM dalam perekonomian Indonesia menyatakan bahwa UKM (Usaha Kecil dan Menengah) merupakan kegiatan usaha yang banyak diminati setelah terjadinya krisis ekonomi yang berdampak pada PHK pada perusahaan-perusahaan besar, Begitu pula dengan Kota Langsa. Salah satu UKM yang unggul dan banyak diminati di kota Langsa adalah terasi, kecap dan touco.Produk-produk yang dihasilkan pun bervariasi. Jika dicermati banyak produk yang apabila dikembangkan dapat memiliki nilai tinggi dan dapat bersaing dengan produk-produk asing. Namun disayangkan, pelaku UKM di Indonesia belum memperhatikan pentingnya pengetahuan akuntansi dan tidak menggunakan informasi akuntansi dalam menjalankan bisnisnya.

Kesadaran akan pentingnya pembukuan justru sering timbul ketika mereka harus berhadapan dengan institusi atau pihak lain yang mensyaratkan adanya laporan keuangan atau istilah modernya akuntansi, untuk kegiatan tertentu. Misalnya, untuk kepentingan meminjam modal ke bank, keberhasilan usaha kecil tidak lepas dari kerja keras pemilik yang mengelolanya.

Salah seorang manajer klinik usaha kecil dan koperasi Ikatan Akuntan Indonesia (IAI), Idrus (2000), menyatakan bahwa para pengusaha kecil tidak memiliki pengetahuan akuntansi, dan banyak diantara mereka yang belum memahami pentingnya pencatatan dan pembukuan bagi kelangsungan usaha. Pengusaha kecil memandang bahwa proses akuntansi tidak terlalu penting untuk diterapkan. Dalam menjalankan aktivitas usaha seringkali orang merasa kesulitan dalam melakukan pencatatan terhadap apa yang terjadi di perusahaan. Kesulitan itu menyangkut aktivitas dan penilaian atas hasil yang di capai oleh setiap usaha. Apalagi jika harus dilakukan pengukuran dan penilaian atas aktivitas yang terjadi dalam kegiatan usaha.

Pencatatan dilakukan hanya dengan melihat berapa uang yang masuk di selisihkan dengan uang yang keluar, tanpa melihat pengeluaran itu untuk atau dari alokasi kegiatan usaha ataupun non usaha. Seringkali dalam skala usaha kecil menengah hasil usaha dikatakan bagus jika mendapatkan keuntungan yang lebih banyak di bandingkan keuntungan sebelumnya. Padahal tolok ukur dari keberhasilan tidak di ukur dari pendapatan saja. Perlu pengukuran atas transaksi atau kegiatan yang terjadi, perlu pengelompokan serta perlupengihtisaran transaksi-transaksi tersebut. Dengan demikian setiap aktivitas yang berhubungan dengan usaha perusahaan dapat dicatat dan dilaporkan dengan benar.

Untuk mengembangkan usaha dapat dilakukan dengan cara pengukuran atau penilaian dari setiap aktivitas usaha. Oleh sebab itu pengusaha perlu menciptakan sebuah sistem pencatatan yang baik dari setiap aktivitas usaha tersebut. Dengan sistem pencatatan yang baik maka akan di hasilkan pelaporan hasil usaha dan kondisi peru- 
sahaan yang benar. Hal ini bisa dilakukan jika unit usaha melakukan sistem akuntansi yang disesuaikan dengan jenis usahanya. Jika perusahaan belum mampu untuk menciptakan sistem akuntansi yang baik, minimal UMKM melakukan sistem pembukuan yang baik (Hidayat,2004).

Informasi akuntansi mempunyai peran penting untuk mencapai keberhasilan usaha, termasuk bagi usaha kecil (Megginson et al., 2000). Informasi akuntansi dapat menjadi dasar yang andal bagi pengambilan keputusan-keputusan dalam pengelolaan usaha kecil, antara lain keputusan pengembangan pasar, penetapan harga, dan lain-lain. Dalam hubungan usaha kecil dengan pemerintah dan kreditur (bank), penyediaan informasi akuntansi juga diperlukan. Kewajiban menyelenggarakan pencatatan akuntansi yang baik bagi usaha kecil di Indonesia sebenarnya telah tersirat dalam Undang-undang usaha kecil no. 9 tahun 1995 dan dalam Undang-undang perpajakan. Pemerintah maupun komunitas akuntansi telah menegaskan pentingnya pencatatan dan penyelenggaraan informasi akuntansi bagi usaha kecil, walaupun dalam kenyataannya desakan hukum (law enforcement) dari regulator belum memadai. (Pinasti 2007). Holmes dan Nicholls 2008 berpendapat bahwa Informasi akuntansi merupakan informasi kuatitatif tentang entitas ekonomi yang bermanfaat untuk pengambilan keputusan ekonomi dalam menentukan pilihan-pilihan diantara alternative-alternatif tindakan, serta bermanfaat untuk perencanaan strategis, pengawasan manajemen operasional.

Peranan akuntansi adalah memberikan informasi sebagai dasar untuk pengambilan keputusan bisnis. Menurut Pinasti (2007: 322) informasi akuntansi dapat menjadi dasar yang andal bagi pengambilan keputusan-keputusan dalam pengelolaan usaha kecil, antara lain keputusan pengembangan pasar, penetapan harga, dan lainlain. Pengambilan keputusan yang tepat dapat menentukan keberhasilan dari sebuah usaha. Oleh karena itu, informasi akuntansi memiliki peran yang penting bagi pelaku bisnis dalam mencapai keberhasilan usahanya, termasuk bagi Usaha Mikro, Kecil dan Menengah (UMKM). Mengingat bahwa UMKM menghadapi berbagai permasalahan seperti lemahnya jaringan usaha, keterbatasan kemampuan penetrasi pasar dan diversifikasi pasar, skala ekonomi terlalu kecil sehingga sukar menekan biaya, margin keuntungan sangat kecil, dan lebih jauh lagi UKM tidak memiliki keunggulan kompetitif (Rahmana, 2012:15).

Keberhasilan usaha kecil tidak lepas dari kerja keras pemilik yang menegelolanya. Kebijakan-kebijkan manajemen yang merupakan kunci keberhasilan suatu perusahaan dipengaruhi oleh pemilik dalam menggunakan informasi akuntansi karena Setiap kegiatan bisnis tentunya memerlukan pencatatan akuntansi agar setiap transaksi yang terjadi bisa di ketahui secara jelas. 
Obyek penelitian ini adalah UMKM yang bergerak di bidang usaha terasi, Kecap dan Tauco di Kota Langsa sebagai obyek penelitian dikarenakan terasi, Kecap dan Tauco adalah salah satu UMKM unggulan di Kota Langsa. Tulisan ini mencoba menjawab pertanyaan berikut: Bagaimana peran Infomasi Akuntansi terhadap keberhasilan UMKM di Kota Langsa ? dan Apakah informasi akuntansi berperan dalam meningkatkan keberhasilan UMKM di Kota Langsa?.

\section{LANDASAN TEORI}

\section{Informasi Akuntansi}

Prasetya (2006) dikutip dalam Permana (2014) menyatakan bahwa informasi adalah data-data yang telah diproses dengan cara-cara tertentu sehingga berguna untuk pengambilan keputusan. Informasi yang digunakan dalam perusahaan dibagi menjadi informasi kuantitatif dan informasi non kuantitatif.

Menurut Belkaoui (2000:39), informasi akuntansi digolongkan menjadi tiga jenis yaitu:

\section{Informasi Operasi}

Informasi ini berupa data mentah, informasi operasi yang terdapat pada perusahaan manufaktur antara lain:
a. Informasi produksi
b. Informasi pembelian
c. Pemakaian bahan baku
d. Informasi penggajian
e. Informasi penjualan

Informasi operasi digunakan sebagai alat penilaian atas pelaksanaan kegiatan operasional perusahaan, baik secara keseluruhan, bagian-bagian maupun individu-individu yang diberi wewenang dan tanggung jawab, dan sebagai alat untuk mengukur tingkat biaya kegiatan-kegiatan usaha yang dilaksanakan perusahaan.

\section{Informasi Akuntansi Manajemen}

Informasi ini khusus ditujukan untuk kepentingan manajemen, informasi ini digunakan dalam tiga fungsi manajemen, yaitu:
a. Perencanaan
b. Implementasi
c. Pengendalian

Informasi akuntansi manajemen ini dihasilkan oleh sistem pengolahan informasi keuangan. Informasi akuntansi manajemen ini disajikan kepada manajemen peru- 
sahaan dalam berbagai laporan, seperti: laporan anggaran, laporan penjualan, laporan biaya produksi, laporan biaya menurut pusat pertanggungjawaban, laporan biaya menurut aktivitas, dan lain-lain. Bagi manajemen, informasi akuntansi digunakan untuk menyusun perencanaan dan pengawasan terhadap operasional perusahaan atau jalannya perusahaan, mengevaluasi kemajuan yang dicapai dalam usaha mencapai tujuan dan melakukan tindakan koreksi yang diperlukan.

\section{Informasi Akuntansi Keuangan}

Informasi akuntansi keuangan digunakan oleh manajer maupun pihak eksternal perusahaan, dengan tujuan untuk menyediakan informasi tentang posisi keuangan, kinerja serta perubahan keuangan suatu perusahaan yang bermanfaat bagi sejumlah besar pemakai dalam pengambilan keputusan ekonomi.

Bagi pihak ekstenal informasi akuntansi sebagai dasar penentuan pajak penghasilan yang menjadi tanggungan perusahaan, dan sebagai dasar untuk menyusun statistik pendapatan nasional dan statistik lainnya serta informasi akuntansi untuk dapat mengetahui stabilitas dan profitabilitas perusahaan, selain itu informasi akuntansi tersebut juga diperlukan untuk menilai kemampuan perusahaan dalam memberikan balas jasa.

\section{Keberhasilan Usaha}

Keberhasilan usaha adalah suatu kedaan yang mengagambarkan lebih dari pada yang lain yang sederajat (lestari, 2011). Menurut Suyatno (2010:179) berkaitan dengan faktor penentu keberhasilan usaha industri kecil ini, hasil penelitiannya menemukan bahwa keberhasilan usaha kecil ditandai oleh inovasi, perilaku mau mengambil resiko. Begitu juga hasil penelitian Murphy dalam sumber yang sama menemukan bahwa keberhasilan usaha kecil disumbangkan oleh kerja keras, dedikasi, dan komitmen terhadap pelayanan dan kualitas. Berbagai faktor penentu keberhasilan usaha industri kecil hasil identifikasi penelitian Luch tersebut pada dasarnya adalah cerminan dari kemampuan usaha (pengetahuan, sikap dan keterampilan), pengalaman yang relevan, motivasi kerja dan tingkat pendidikan seseorang pengusaha.

Sehingga dapat diketahui bahwa keberhasilan usaha dapat dipengaruhi oleh kemampuan usaha yang tercermin diantarannya melalui pengetahuan, sikap, dan keterampilan dari pengusaha. Keberhasilan suatu usaha diidentikkan dengan laba atau penambahan material yang dihasilkan oleh pengusaha, tetapi pada dasarnya keberhasilan usaha tidak hanya dilihat dari hasil secara fisik tetapi keberhasilan usaha dirasakan oleh pengusaha dapat berupa panggilan pribadi atau kepuasaan batin.

Kriteria keberhasilan usaha kecil dalam penelitian Riyanti, (2003) tentang wirausaha kecil di Singapura menunjukan bahwa dari $85 \%$ responden yang menjawab, $70 \%$ 
wirausaha menggunakan net laba bersih (profit growth) untuk mengukur keberhasilan usaha, disusul oleh laba penjualan (sales revenue growth, 61\%), laba setelah pajak (return on investment, 50\%), dan pangsa pasar (market share, 48\%). Selanjutnya, $38 \%$ dari wirausaha yang menggunakan kriteria keberhasilan laba bersih (net profit growth), berpendapat bahwa prestasi 6-10\% pertumbuhan pertahun merupakan indikator keberhasilan usaha. Untuk mendukung uraian diatas, criteria keberhasilan usaha adalah usaha-usaha yang mengalami peningkatan $25 \%$ dari keadaan ketika perusahaan didirikan. Meskipun hanya 25\%, karena yang dilihat adalah peningkatan dalam akumulasi modal, jumlah produksi, jumlah pelanggan, perluasan usaha dan perbaikan fisik maka kriteria tersebut dinilai cukup signifikan sebagai kriteria keberhasilan usaha (Riyanti, 2003).

Informasi akuntansi dapat menjadi dasar untuk pengambilan keputusan bisnis sehingga mempunyai pengaruh yang sangat penting bagi pencapaian keberhasilan usaha, termasuk UMKM. Dengan kurangnya pengetahuan dalam pembukuan, otomatis menghambat mereka menjalankan kegiatan pembukuan keuangan. Informasi akuntansi yang berupa catatan keuangan dapat digunakan oleh pemilik UMKM untuk mengetahui secara persis berapa pendapatan yang diterima, berapa biaya operasi yang seharusnya dikeluarkan dan berapa yang seharusnya masih tersisa.

Dari beberapa definisi keberhasilan usaha menurut beberapa sumber, dapat diringkas pada tabel berikut:

Tabel 1.

Kriteria Keberhasilan Usaha

\begin{tabular}{ll}
\hline \multirow{2}{*}{ Rujukan } & \multicolumn{2}{c}{ Indikator Keberhasilan-kepala Kol } \\
\cline { 2 - 3 } & 1. Jumlah Karyawan: \\
& a. Banyaknya karyawan yang bekerja \\
& b. Rendahnya Turn over karyawan \\
Haryadi & d. Tingkat lamanya bekerja karyawan \\
& 2. Peningkatan Omzet Penjualan \\
& a. Tingkat Banyaknya order \\
& b. Tingkat Promosi Pemesanan \\
& c. Tingkat Harga Yang ditawarkan \\
& d. Tingkat Penghasilan dari penjualan
\end{tabular}




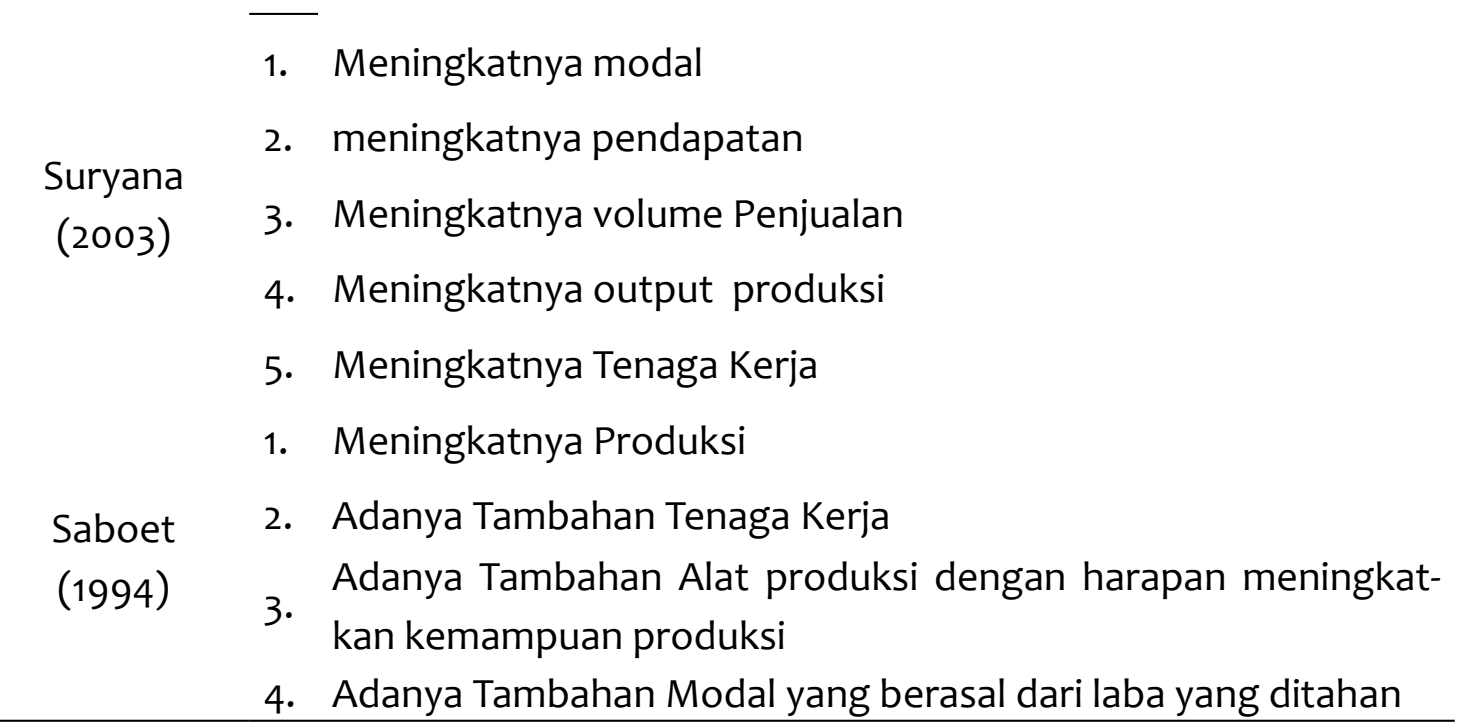

\section{UMKM}

UMKM adalah unit usaha produktif yang berdiri sendiri, yang dilakukan oleh orang perorangan atau Badan Usaha disemua sektor ekonomi (Tambunan, 2012:2). Pada prinsipnya, perbedaan antara Usaha Mikro (UMi), Usaha Kecil (UK), Usaha Menengah (UM) dan Usaha Besar (UB) umumnya didasarkan pada nilai asset awal (tidak termasuk tanah dan bangunan), omset rata-rata pertahun atau jumlah pekerja tetap.

Di Indonesia, definisi UMKM diatur berdasarkan Undang-Undang Republik Indonesia Nomor 20 Tahun 2008 tentang Usaha Mikro, Kecil, dan Menengah. Definisi menurut UU No. 20 Tahun 2008 tersebut adalah sebagai berikut:

1. Definisi

Usaha Mikro adalah usaha produktif milik orang perorangan dan/atau badan usaha yang memenuhi kriteria Usaha Mikro sebagaimana diatur dalam Undang-Undang ini

Usaha kecil adalah usaha ekonomi produktif yang berdiri sendiri, yang dilakukan oleh orang perorangan atau badan usaha yang bukan merupakan anak perusahan atau bukan cabang perusahaan yang dimiliki, dikuasai, atau menjadi bagian baik langsung maupun tidak langsung dari usaha menengah atau usaha besar yang memenuhi kriteria Usaha Kecil sebagaimana dimaksud dalam undang-undang ini.

Usaha Menengah adalah usaha ekonomi produktif yang berdiri sendiri, yang dilakukan oleh orang perorangan atau badan usaha yang bukan merupakan anak perusahan atau cabang perusahaan yang dimiliki, dikuasai, atau menjadi bagian baik langsung maupun tidak langsung dengan Usaha Mikro atau usaha besar dengan jumlah kekayaan bersih atau hasil penjualan tahunan sebagaimana diatur dalam Undang-Undang. 


\section{Kriteria}

Menurut Haryadi (1998) dalam Wibowo (2013), kriteria keberhasilan usaha dilihat dari peningkatan omzet penjualan dapat dibagi sebagai berikut:
a. Tingkat banyaknya order
b. Tingkat promosi pesanan
c. Tingkat harga yang ditawarkan
d. Tingkat penghasilan dari penjualan

Berdasarkan Undang-Undang Republik Indonesia Nomor 20 Tahun 2008 Tentang Usaha Mikro,Kecil, Dan Menengah, UMKM memiliki kriteria sebagai berikut :

1) Kriteria Usaha Mikro adalah sebagai berikut :

a) Memiliki kekayaan bersih paling banyak Rp 50.000.000,- (lima puluh juta rupiah) tidak termasuk tanah dan bangunan tempat usaha; atau

b) Memiliki hasil penjualan tahunan paling banyak Rp 300.000.000,- (tiga ratus juta rupiah)

2) Kriteria Usaha Kecil adalah sebagai berikut:

a) Memiliki kekayaan bersih lebih dari Rp 50.000.000,- (lima puluh juta rupiah) sampai dengan paling banyak Rp 500.000.000,- (lima ratus juta rupiah) tidak termasuk tanah dan bangunan tempat usaha

b) Memiliki hasil penjualan tahunan lebih dari Rp 300.000.000,- (tiga ratus juta rupiah) sampai dengan paling banyak Rp 2.500.000.000,- (dua milyar lima ratus juta rupiah).

3) Kriteria Usaha Menengah adalah sebagai berikut:

a) Memiliki kekayaan bersih lebih dari Rp 500.000.000,- (lima ratus juta rupiah) sampai dengan paling banyak Rp 10.000.000.000,- (sepuluh milyar rupiah) tidak termasuk tanah dan bangunan tempat usaha

b) Memiliki hasil penjualan tahunan lebih dari Rp 2.500.000.000,- (dua milyar lima ratus juta rupiah) sampai dengan paling banyak Rp 50.000.000.000,(lima puluh milyar rupiah).

Berdasarkan kriteria tersebut diatas maka UMKM dapat dibagi berdasarkan kepemilikan asset dan omset. Hal tersebut dapat dilihat sebagai berikut :

Tabel 1.

Kriteria UMKM

\begin{tabular}{clcc}
\hline & & \multicolumn{2}{c}{ Kriteria } \\
\cline { 3 - 4 } No & & Aset & Omset \\
\hline 1 & Usaha Mikro & Max 50 Jt & Max 300 jt \\
2 & Usaha Kecil & $>50$ juta -500 juta & $>300$ juta-2,5 M \\
3 & Usaha Menengah & $>500$ juta $-10 \mathrm{M}$ & $>2,5 \mathrm{M}-50 \mathrm{M}$ \\
\hline
\end{tabular}


Yang dimaksud dengan kekayaan bersih adalah hasil pengurangan total nilai kekayaan usaha (asset) dengan total nilai kewajiban, tidak termasuk tanah dan bangunan tempat usaha.

\section{METODE}

Penelitian ini menggunakan pendekatan penelitian kualitatif deskriptif. Jenis data yang digunakan dalam penelitian ini adalah data primer yang diperoleh dari penyebaran wawancara yang mendalam terhadap pelaku usaha terasi, kecap dan touco. sedangkan data sekunder yang di gunakan adalah data yang di peroleh dari Dinas Perindustrian, Perdagangan, Koperasi dan UMKM di Kota Langsa. Populasi dalam penelitian adalah UMKM yang terdaftar di Dinas Perindustrian, Perdagangan, Koperasi dan UMKM di Kota Langsa, terkhusus pada jenis kegiatan usaha pembuatan terasi, Kecap dan tauco

Adapun yang menjadi kriteria dalam pengambilan sampel adalah sebagai berikut:

1. UMKM terasi, kecap dan touco yang memiliki jumlah tenaga kerja, produksi dan investasi yang tinggi

2. UMKM yang telah berdiri lebih dari 5 tahun, dikarenakan UMKM yang berdiri lebih dari 5 tahun diasumsikan relatif lebih stabil usahanya.

Data-data yang diperlukan dalam penelitian ini, dikumpulkan melalui tiga cara yaitu: Observasi, Wawancara, Dokumentasi.

Analisis data dilakukan secara berkesinambungan dari awal sampai akhir, di lapangan maupun di luar lapangan. Dalam hal ini digunakan teknik analisis data yang dikemukakan oleh Miles dan Huberman, yaitu reduksi data, penyajian data, interpretasi data, dan kesimpulan.

\section{HASIL DAN PEMBAHASAN}

Usaha Mikro Kecil Menengah (UMKM) yang terdaftar di disperindag kota Langsa dari tahun 2016 sampai dengan 2018 sebanyak 79 usaha. Usaha Mikro Kecil Menengah (UMKM) yang bergerak di bidang terasi berjumlah 30 usaha, sedangkan kecap hanya 1 usaha. Diantaranya ada yang memiliki tenaga kerja, produksi dan nilai produksi yang rendah dan tinggi. Fokus peneliti hanya pada usaha terasi, kecap dan tuoco yang memiliki jumlah tenaga kerja, nilai investasi dan nilai produksi yang tinggi.

Berikut data mengenai jumlah keseluruhan UMKM yang bergerak dibidang terasi dan kecap yang memiliki jumlah tenaga kerja, nilai investasi dan nilai produksi 
yang tinggi di kota Langsa:

Tabel 4.1

Daftar UMKM Yang Bergerak di Bidang Terasi dan Kecap

\begin{tabular}{|c|c|c|c|c|c|c|c|}
\hline \multirow{2}{*}{ No } & \multirow{2}{*}{$\begin{array}{l}\text { Nama Perusa- } \\
\text { haan }\end{array}$} & \multirow{2}{*}{ Nama Pemilik } & \multirow{2}{*}{$\begin{array}{l}\text { Tenaga } \\
\text { Kerja }\end{array}$} & \multirow{2}{*}{$\begin{array}{c}\text { Nilai } \\
\text { Investasi } \\
\text { (RP.000) }\end{array}$} & \multicolumn{2}{|c|}{$\begin{array}{l}\text { Kapasitas } \\
\text { Produksi }\end{array}$} & \multirow{2}{*}{$\begin{array}{c}\text { Nilai } \\
\text { produksi } \\
(\mathrm{RP} .000)\end{array}$} \\
\hline & & & & & Jumlah & Sat & \\
\hline 1 & $\begin{array}{l}\text { KUBE -EM Beu- } \\
\text { lacan }\end{array}$ & Yusuf Itam & 4 & 25000 & 180.000 & $\mathrm{Kg}$ & 690.000 \\
\hline 2 & Faudah Jaya & M.Ali & 5 & 1500 & 12 & Ton & 43.250 .000 \\
\hline 3 & Awaina & Sulaiman B & 4 & 1500 & 10 & Ton & 500.000 \\
\hline 4 & Bina Bersama & Muhammad B & 3 & 2000 & 24 & Ton & 8.640 .000 \\
\hline 5 & $\begin{array}{l}\text { Taci Usaha } \\
\text { Terasi }\end{array}$ & Aminati & 4 & 10.000 & 120 & Ton & 36.000 .000 \\
\hline 6 & Yunus Terasi & M.Yunus & 4 & 2000 & 48 & Ton & 17.280 .000 \\
\hline 7 & SBR Terasi & Saiful Bahri & 12 & 3000 & 36 & Ton & 1.080 .000 \\
\hline 8 & Duriatina Terasi & Duriatina & 5 & 1000 & 12 & Ton & 360.000 \\
\hline 9 & Ingin Jaya & Ari Yuna dewi & 4 & 1000 & 11 & Ton & 400.000 \\
\hline 10 & $\begin{array}{l}\text { PT Langsa Jaya } \\
\text { Abadi }\end{array}$ & Koko & 8 & 20.000 & 150 & Ton & 50.000 .000 \\
\hline
\end{tabular}

Sumber: Laporan Disperindag Kota Langsa

\section{PERANAN INFORMASI AKUNTANSI TERHADAP KEBERHASILAN UMKM DI KOTA LANGSA}

Berdasarkan deskripsi informan (pengusaha terasi dan kecap) yang diperoleh dari hasil wawancara, diidentifikasi bahwa dalam menjalankan usahanya, terdapat sebagian pengusaha terasi telah menggunakan informasi akuntansi secara keseluruhan dan beranggapan bahwa informasi akuntansi memiliki peranan terhadap keberhasilan usaha meskipun mereka belum menggunakan informasi akuntansi secara keseluruhan. Seperti pernyataan yang dinyatakan oleh beberapa informan:

"Terkait dengan informasi akuntansi yang terdiri dari informasi operasi, informasi manajemen dan informasi akuntansi keuangan, saya sudah menggunakannya secara keseluruhan meskipun belum tertata secara rapi. Dengan adanya informasi akuntansi saya bisa mengetahui sejauh mana tingkat keberhasilan usaha yang saya jalankan" (wawancara yunus terasi)

"Dalam menjalan usaha terasi, saya sudah menggunakan informasi akuntansi, akan tetapi informasi akuntansi tersebut tidak saya buat dalam bentuk tulisan atau laporan tetapi menurut perkiraan saya sendiri,sesuai dengan kebiasaan usaha terasi yang saya jalankan, dengan perkiraan tersebut saya bisa mengetahui berapa yang harus saya produksi dan berapa tingkat pendapatan yang saya peroleh.dengan adanya informasi akuntansi, usaha terasi yang saya jalankan 
lebih meningkat pendapatannya dan lebih terarah dibandingkan tanpa menggunakan informasi akuntansi, meskipun informasi akuntansi yang saya gunakan belum tersusun sesuai standar akuntansi" (wawancara KUBE EM)

Hal yang serupa juga dikatakan oleh pemilik usaha terasi yang lainnya seperti "AWAINA" dan "FAUDAH JAYA". Tidak jauh berbeda dengan pernyataan dari pemilik usaha kecap, yang menyatakan bahwa "Dalam menjalankan usahanya, saya sudah menggunakan informasi akuntansi secara keselurahan baik tertulis maupun tidak karena dengan informasi akuntansi saya lebih mudah untuk mengetahui kondisi usaha saya berhasil atau tidak dengan melihat tingkat perolehan laba perusahaan".(wawancara usaha Kecap)

Terkait informasi yang diterima dari para informan (pengusaha terasi dan kecap) seperti tersebut di atas, maka dapat disimpulkan bahwa informasi akuntansi mempunyai peranan terhadap keberhasilan usaha meskipun mereka belum menggunakan informasi akuntansi yang sesuai dengan standar. Dalam pelaksanaannya, dengan adanya informasi akuntansi maka pengusaha terasi dan kecap dapat mengambil keputusan ekonomi dalam menentukan pilihan-pilihan diantara alternatif-alternatif tindakan sehingga usaha yang dijalankannya dapat terus bertambah baik dari segi modal, pendapatan, volume penjualan, output produksi dan tenaga kerja. Contohnya seperti penggunaan informasi bagi manajer dalam melaksanakan fungsinya setiap manajer memerlukan informasi, baik informasi kuantitatif maupun informasi kualitatif

Pada saat melakukan Focus Group Discussion yang dilaksanakan di Aula WRH Coffe bersama dengan beberapa orang Dosen, beberapa pelaku usaha terasi, touco dan kecap,pegawai Disperindag Kota Langsa dan pimpinan Disperindag Kota Langsa, pimpinan Disperindag Kota Langsa mengatakan bahwa “ permasalahan yang terjadi di kalangan para pelaku usaha UMKM terutama terasi, touco dan kecap yang menjadi fokus penelitian peneliti berkaitan dengan informasi akuntansi adalah para pelaku usaha belum sepenuhnya paham bagaimana penggunaan informasi akuntansi yang tepat sehingga informasi tersebut dapat meningkatkan keberhasilan usaha yang mereka jalankan, ditambah lagi mereka tidak paham dengan proses akuntansi seperti pembuatan laporan keuangan untuk usaha mereka, hal ini yang membuat para pelaku usaha terasi, touco dan kecap memilih metode sendiri yaitu dengan cara penaksiran berdasarkan daftar kwitansi untuk memproduksi terasi, touco dan kecap".

Solusi yang diharapkan oleh pimpinan,pegawai disperindag kota Langsa dan para pelaku usaha adalah, dengan adanya penelitian yang dilakukan oleh peneliti berkaitan dengan informasi akuntansi maka para pelaku terasi, touco dan kecap setidaknya mereka dapat gambaran bagaimana peranan dan pentingnya informasi akuntansi terhadap keberhasilan usaha yang mereka jalankan. Pimpinan disperindag kota Langsa menambahkan juga seharusnya dengan adanya penelitian ini maka pihak peneliti 
tidak hanya meneliti saja akan tetapi sekaligus mengajarkan bagaimana pembukuan yang benar, sesuai dengan standar sehingga proses pengambilan informasi akuntansinya dapat $100 \%$ tercapai dan berhasil meningkatkan usaha terasi, touco dan kecap.

\section{INFOMASI AKUNTANSI TERHADAP PENINGKATAN KEBERHASILAN UMKM DI KOTA LANGSA}

Menurut hasil pengamatan peneliti informasi akuntansi dapat meningkatkan keberhasilan UMKM di Kota Langsa, hal ini disampaikan oleh salah satu informan, yang menyatakan bahwa " dengan penggunaan informasi, usaha terasi yang saya jalankan semakin berkembang dibandingkan tanpa menggunakan informasi akuntansi" (Duriatina Terasi). Hal tersebut dibenarkan oleh bapak yunus pemilik usaha Yunus Terasi, beliau mengatakan bahwa dengan penggunaan informasi akuntansi maka beliau dapat mengetahui berapa biaya-biaya yang harus beliau keluarkan untuk memproduksi/menjalankan usaha terasinya, ditambah lagi dengan penggunaan informasi akuntansi laporan keuangan rumah tangga tidak akan tercampur dengan laporan keuangan usaha. Dan semenjak beliau menggunakan informasi akuntansi usaha beliau semakin berkembang dan mengalami peningkatan, hal ini dibuktikan dengan meningkatnya omzet, bertambahnya jumlah karyawan, meningkatnya volume penjualan dan meningkatnya jumlah pelanggan dan transaksi.

Pemilik usaha kecap dan touco juga beranggapan sama dengan para pemilik usaha terasi meskipun dari dulu usaha yang beliau jalankan sudah menggunakan informasi akuntansi secara lengkap, dan beliau mengatakan hal yang sama dengan para pelaku usaha terasi bahwa " penggunaan informasi akuntansi dapat meningkatkan keberhasilan usaha, hal ini sudah terbukti terhadap usaha yang beliau jalankan, dengan penggunaan informasi akuntansi beliau bisa mengetahui akuntansi yag berkaitan dengan operasi yang terdiri dari biaya bahan mentah, penggajian, biaya produksi, penjualan sehingga pada akhirnya belaiu dapat mengambil keputusan dan mengendalikan usaha yang kecap dan touco yag beliau jalankan".

Dari hasil pernyataan wawancara di atas dapat disimpulkan bahwa informasi akuntansi dapat meningkatkan keberhasilan UMKM di Kota Langsa. Ditambah lagi dengan hasil jawaban wawancara penelitian terkait dengan peranan infomasi akuntansi terhadap keberhasilan UMKM di kota Langsa, dapat disimpulkan bahwa informasi akuntansi memiliki peran yang sangat penting dan dapat meningkatkan keberhasilan UMKM di Kota Langsa, hal ini ditunjukkan oleh mayoritas responden sebanyak 100\% menjawab respon "setuju" terhadap pertanyaan kuesioner "apakah saudara/i setuju bahwa informasi operasi berperan terhadap keberhasilan usaha?”. Sedangkan untuk pertanyaan "apakah saudara/i setuju bahwa informasi Manajemen berperan terhadap keberhasilan usaha?" juga mendapat respon mayoritas "setuju” 
dari pelaku usaha terasi, touco dan kecap Kota Langsa atau sebanyak 100\%. Kemudian untuk pertanyaan "apakah saudara/i setuju bahwa informasi akuntansi keuangan berperan terhadap keberhasilan usaha?" juga mendapatkan respon mayoritas "setuju" sebanyak 100\%. Dari statistik frekuensi yang diperoleh melalui kuesioner, dapat disimpulkan bahwa informasi akuntansi memiliki peran yang sangat penting terhadap keberhasilan UMKM di kota Langsa.

\section{SIMPULAN}

Dari uraian tentang Peranan Informasi Akuntansi Terhadap Keberhasilan UMKM di Kota Langsa di atas, maka dapat disimpulkan sebagai berikut:

1. Informasi akuntansi memiliki peran terhadap keberhasilan UMKM di kota Langsa dengan adanya penggunaan informasi akuntansi yang terdiri dari informasi operasi, informasi manajemen dan informasi akuntansi keuangan maka pelaku UMKM ( usaha terasi, kecap dan touce) kota Langsa dapat mengetahui total biaya-biaya yang dikeluarkan selama proses produksi, sehingga data tersebut dapat dibandingkan dengan pendapatan yang diperoleh pada tahun berjalan atau tahun sebelumnya.

2. Informasi akuntansi dapat meningkatkan keberhasilan UMKM di kota Langsa. Dalam hal ini para pelaku UMKM ( usaha terasi, kecap dan touce) kota Langsa beranggapan bahwa dengan menggunakan informasi akuntansi, usaha yang mereka jalankan lebih berhasil dibandingkan tanpa menggunakan informasi akuntansi, contohnya informasi akuntansi yang berkaitan dengan operasi, saat mereka menggunakan informasi operasi mereka dapat mengetahui informasi produksi, informasi pembelian, pemakaian bahan baku, informasi penggajian dan informasi penjualan, dengan informasi tersebut para pelaku usaha dapat memonitoring usaha mereka sehingga mereka mengetahui usahanya berkembang atau tidak.

\section{PUSTAKA ACUAN}

Belkaoui,A.R. 2000. Teori Akuntansi. Edisi Pertama, Salemba Empat, Jakarta Kasmir, 2016. Kewirausahaan. Pt. Raja Grafindo Persada, Jakarta

Lestari, F, 2011. Pengaruh Jiwa Kewirausahaan Dan Kreativitas Terhadap Keberhasilan Usaha Pada Sentra Industri Rajutan Binong Jati Bandung. Jurnal Ekonomi Bisnis Dan Akuntansi No.1/Vol. 1/ September.

Pinasti, M. 2007. " Pengaruh Penyelenggaraan Dan Penggunaan Informasi Akuntansi Terhadap Persepsi Pengusaha Kecil Atas Informasi Akuntansi : Suatu Riset Eksperimen". Jurnal Riset Akuntansi Indonesia, Vol 10, No 3, September 
2007

Suryana, 2003. Kewirausahaan. Salemba Empat: Jakarta

Suyatno Purnama, Chandan. 2010. Motivasi Dan Kemampuan Usaha Dalam Meningkatkan

Keberhasilan Usaha Industri Kecil (Studi Pada Industri Kecil Sepatu Di Jawa Timur). Jurnal Manajemen Dan Kewirausahaan

Tania. 2008.Pengaruh Pengalaman Usaha Dan Pengetahuan Akuntansi Terhadap Penggunaan Informasi Akuntansi Pada Usaha Dagang Di Kota Salatiga. Fakultas Ekonomika Dan Bisnis Universitas Satya Wacana Salatiga.

Tambunan, Tulus, 2012, Memahami Krisis Siasat Mebangun Kebijakan Ekonomi, Jakarta. http://disperindagkop.kotalangsa.go.id 